\title{
Klustering Jumlah Penumpang pada Halte Bus Rapid Transit Kota Tangerang
}

\author{
Erni Dianawati ${ }^{1}$, Putri Previa Yanti ${ }^{2}$, Yulia Suryandari ${ }^{3}$ \\ Sekolah Teknik Elektro dan Informatika \\ Institut Teknologi Bandung \\ Bandung, Indonesia \\ ernidianawatiw@students.itb.ac.id ${ }^{1}$,putriprevia@students.itb.ac.id², \\ yulia.suryandari@students.itb.ac.id ${ }^{3}$
}

\begin{abstract}
Bus Rapid Transit (BRT) Trans Tangerang is a local public transportation system developed in the main corridor of the Tangerang City area as well as a feeder for Transjabodetabek and rail transport. BRT Trans Tangerang is one part of the Bus Rapid Transit program which is implemented and launched by Department of Transportation. The BRT Trans Tangerang system began operating at the beginning of December 2016. Some problems faced by Trans Tangerang Bus Rapid Transit such as the number of passengers that need to be increased to reduce congestion in the city of Tangerang and the placement of the right bus stops to attract passengers. Therefore, to overcome this problem, data and information about BRT Trans Tangerang are needed to find patterns of passenger distribution. The process of finding this information can be done by using data mining method. Within this method, there is a clustering technique which is useful to clustering all data in groups which have similar data. The algorithm used to classify the data is called simple k-means algorithm. In this study, all the data will be clustered into five cluster. The clustering results have almost the same nature between the data in one cluster, namely the total number of passengers per month, so that by performing clustering characteristics, knowledge of the busy schedule of passengers in one day can help related parties to anticipate the density of passengers on certain days.
\end{abstract}

\section{Keywords-Clustering, passenger, bus rapid transit, Tangerang City}

\section{Pendahuluan}

Menurut laporan yang dikeluarkan oleh Badan Pusat Statistik Kota Tangerang pada tahun 2017 dan 2018, populasi kendaraan bukan umum objek pajak di Kota Tangerang meningkat sebesar 0,94\% (722.580 kendaraan pada tahun 2016 menjadi 768.627 kendaraan pada tahun 2017). Berdasarkan studi volume kecepatan di ruas jalan Kota Tangerang yang telah dilakukan oleh Dinas Perhubungan pada tahun 2017, menunjukkan semakin banyaknya titik-titik kritis dengan kecepatan $<10 \mathrm{~km} / \mathrm{jam}$ pada beberapa ruas jalan. Hal ini menunjukkan masih cukup besarnya antusiasme masyarakat untuk menggunakan kendaraan pribadi dibandingkan harus menggunakan angkutan umum yang sudah disediakan. Kondisi tersebut berimbas pada kondisi lalu lintas di Kota Tangerang, sampai tahun 2019 masih tercatat ada 83 titik kemacetan di Kota Tangerang yang belum bisa diatasi sepenuhnya [1]. 


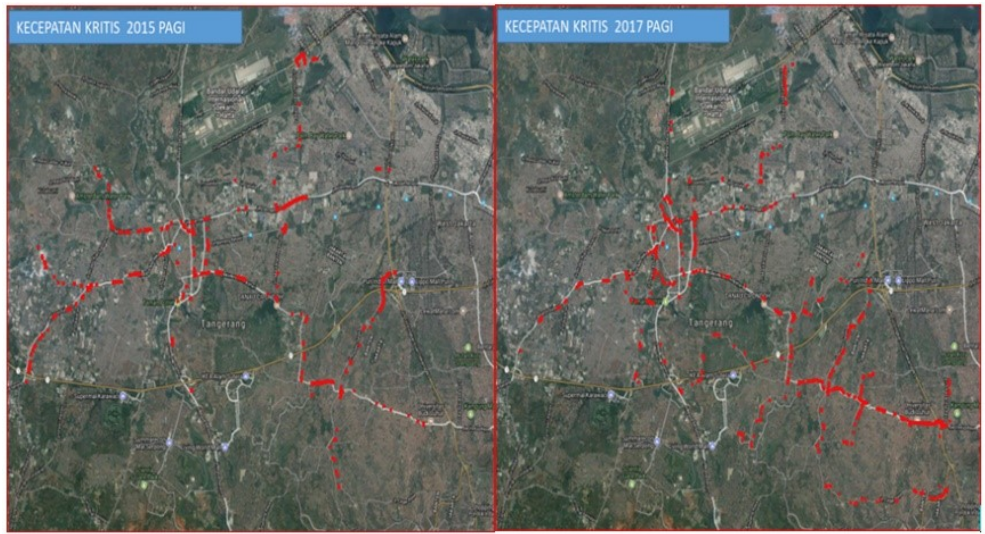

Gambar 1. Perbandingan kecepatan kritis $(<10 \mathrm{Km} / \mathrm{Jam})$ pada pagi hari antara Tahun 2015 dan 2017

BRT Trans Tangerang merupakan sistem angkutan umum lokal yang dikembangkan di koridor utama wilayah Kota Tangerang sekaligus sebagai angkutan pendukung (feeder) bagi angkutan Transjabodetabek dan angkutan kereta api. Pola layanan BRT Trans Tangerang diarahkan sesuai dengan standar pelayanan minimal (SPM) yang ditetapkan, yakni melayani penumpang umum di wilayah Kota Tangerang secara lebih nyaman, aman, teratur, terjadwal, terjangkau, serta terintegrasi.

Sampai dengan tahun 2019, BRT Trans Tangerang sudah tersedia dalam 2 (dua) koridor utama, yaitu Koridor 1 dan Koridor 2 [2]. Koridor 1 melayani rute dari Terminal Poris Plawad ke Jatake dan sebaliknya dengan jarak tempuh sepanjang 17 kilometer. Koridor ini dibuka sejak tahun 2017 dengan melewati beberapa halte sebagai berikut:

1. Halte Terminal Poris Plawad

2. Halte Tanah Tinggi

3. Halte Imigrasi

4. Halte Pesanggarahan

5. Halte Satria

6. Halte PLN

7. Halte Sinar Hati

8. Halte RSU An-Nisa

9. Halte Uwung Jaya

10. Halte Keroncong

Koridor 2 melayani rute dari Terminal Poris Plawad ke Terminal Cibodas. Koridor 2 dibuka sejak Juni 2018 dengan melewati rute Terminal Poris Plawad - Jl. Benteng Betawi - Jl. Jend. Sudirman - J1. Teuku Umar - J1. Imam Bonjol - J1. Kav. Pemda Raya - Jl. Pandan Raya - J1. Bango Raya - J1. Nuri Raya - J1. Betet Raya - J1. Sawo Raya - J1. Empu Barada J1. Borobudur Raya - Terminal Cibodas. Untuk rute sebaliknya yaitu Cibodas-Poris Plawad memiliki rute Terminal Cibodas - Pasar Malabar - J1. Cemara Raya - J1. Beringin Raya - J1. Teuku Umar - Jl. Jend. Sudirman - Jl. Benteng Betawi - Terminal Poris Plawad.

BRT Trans Tangerang mulai beroperasi dari pukul 05:00 sampai dengan pukul 21:00 WIB dengan jumlah perjalanan sebanyak 4 RIT. BRT Trans Tangerang memiliki 10 armada yang beroperasi. Kapasitas penumpang BRT Trans Tangerang adalah 20 penumpang. 


\section{A. Implementasi solusi yang telah dilakukan oleh pemangku kepentingan dan dampaknya serta potensi-potensi pengembangan solusi.}

Beberapa solusi yang telah dilakukan oleh Pemerintah Kota Tangerang antara lain [4]:

a. Area Traffic Control System sebagai bagian dari Intelligent Transportation System dengan memasang beberapa CCTV di beberapa persimpangan yang terhubung dengan monitoring traffic light bertujuan untuk pengaturan lalu lintas dan memudahkan koordinasi dengan pegawai lapangan.

b. Pengoperasian BRT (Bus Rapid Transit) yang dimulai sejak Desember 2016 dengan jalur koridor I pelayanan Terminal Poris Plawad-Jatiuwung dan ditambahkan koridor II dengan jalur Terminal Poris Plawad-Cibodas sejak Juni 2018.

c. Pengintegrasian Angkutan Umum yang dimulai dengan rencana pembangunan Transit Oriented Development (TOD) Kawasan Terminal Poris Plawad.

d. Melakukan Manajemen Rekayasa Lalu Lintas di beberapa titik kemacetan (Pintu Air 10, Jalan Sangiang, Jalan Benteng Betawi,dll).

e. Operasi penertiban Parkir Liar (Jalan Satria Sudirman/ Kawasan Tangerang City/ Kawasan Taman Gajah, Stasiun Tanah Tinggi dan Kawasan Pasar Lama).

\section{B. Perumusan Masalah}

Mengoptimalkan pelayanan angkutan umum yang nyaman merupakan salah satu misi utama dari Dinas Perhubungan Kota Tangerang sebagai salah satu upaya untuk mencapai visi "Mewujudkan Transportasi yang Handal". Keberhasilan kinerja pelayanan angkutan umum dapat terlihat dari nilai load factor. Dilihat dari aspek keberlangsungan penyelenggaraan angkutan umum, semakin tinggi presentase rata-rata load factor maka dapat dikatakan semakin baik, sedangkan dari aspek kenyamanan penumpang, semakin kecil load factor maka dapat dikatakan semakin baik.

\begin{tabular}{|c|c|c|c|c|c|c|c|c|c|c|c|}
\hline \multirow{2}{*}{ No } & \multirow{2}{*}{ PARAMEIER PENILALAN } & \multirow{2}{*}{ SATUAN } & \multicolumn{3}{|c|}{ STANDAR PEILALAN } & \multicolumn{2}{|c|}{ BUSKOTA } & \multicolumn{2}{|c|}{$\begin{array}{l}\text { ANG KUTAN DALAM } \\
\text { KOTA }\end{array}$} & \multicolumn{2}{|c|}{ BRT } \\
\hline & & & $\begin{array}{l}\text { Kurang } \\
\text { (1) }\end{array}$ & \begin{tabular}{|c|} 
Sedang \\
(2)
\end{tabular} & $\begin{array}{r}\text { Baik } \\
(3)\end{array}$ & NILAI & ВОВОт & NILAI & ВОВОт & NILAI & ВОВОТ \\
\hline 1. & Load Factor, Jam Sbuk & $\%$ & $>100$ & $80-100$ & $<80$ & $60,22 \%$ & 3 & $31,95 \%$ & 3 & $39,5 \%$ & 3 \\
\hline 2. & Load Factbr, diluar jam sibuk & $\%$ & $>100$ & $70-100$ & $<70$ & $51,01 \%$ & 3 & 27,3496 & 3 & $39,5 \%$ & 3 \\
\hline 3. & Kecepatan perjalanan & Km/jam & $<5$ & $5-10$ & $>10$ & $>10$ & 3 & 9,44 & 2 & $>10$ & 3 \\
\hline 4. & Headway & Menit & $>15$ & $10-15$ & $<10$ & 51,38 & 1 & 15,63 & 1 & 11,25 & 2 \\
\hline 5. & Waltu perjalanan & Merit/km & $>12$ & $6-12$ & $<6$ & $<6$ & 3 & 6,35 & 2 & 6 & 3 \\
\hline 6. & Waltu pelayenan & Jam & $<13$ & $13-15$ & $>15$ & $13-15$ & 2 & $13-15$ & 2 & 16,5 & 3 \\
\hline 7. & Frebuensi & Kend/ jam & $<4$ & $4-6$ & $>6$ & $<4$ & 1 & 6,43 & 3 & $<4$ & 1 \\
\hline 8. & Jumlah kendaraan yeng beroperasi & $\%$ & $<82$ & $82-100$ & 100 & - & - & - & - & - & - \\
\hline 9. & Waltu tunggu & Menit & $>30$ & $20-30$ & $<20$ & $>30$ & 1 & 7,815 & 3 & $<20$ & 3 \\
\hline 10. & Awal dan akhir per jalaran & & $\begin{array}{c}05.00- \\
18.00 \\
\end{array}$ & \begin{tabular}{|c|}
$05.00-$ \\
20.00 \\
\end{tabular} & $\begin{array}{c}05.00- \\
22.00 \\
\end{array}$ & $\begin{array}{l}05.00- \\
20.00\end{array}$ & 2 & $05.00-20.00$ & 2 & $\begin{array}{c}05.00- \\
22.00\end{array}$ & 3 \\
\hline & TOTAL BOBOT & & & & & & 19 & & 21 & & 24 \\
\hline
\end{tabular}

Gambar 2. Kinerja Angkutan Umum di Wilayah Kota Tangerang berdasarkan survei Tahun 2017

Kinerja angkutan umum baik bus kota, angkutan dalam kota, dan BRT, saat ini masih dibawah $80 \%$. Artinya, penggunaan angkutan umum perkotaan relatif belum menjadi pilihan sebagian masyarakat Kota Tangerang. Dari hasil survei kinerja angkuta n yang telah dilakukan pada jenis angkutan bus kota, angkutan dalam kota dan BRT yang melayani di wilayah Kota Tangerang, maka Bus Kota mempunyai load factor rata-rata sebesar 60,22\%, angkutan dalam kota sebesar $31,93 \%$, dan BRT sebesar 39,5\%.

Berdasarkan survei statis yang telah dilakukan pada titik-titik strategis lintasan trayek angkutan umum yang ada di wilayah Kota Tangerang di Tahun 2016, diperoleh bahwa populasi pengguna angkutan umum sebesar \pm 245.180 orang dengan jumlah penduduk kota Tangerang sebesar 1.750 .030 jiwa. Hal ini menunjukkan hanya $14,01 \%$ penduduk yang memanfaatkan penggunaan angkutan umum. 
Dalam usaha menarik minat masyarakat dalam menggunakan angkutan umum telah dilakukan beberapa solusi:

a. Meningkatkan kenyamanan angkutan umum

b. Pembukaan rute - rute baru BRT

c. Rencana penggunaan sistem e-ticketing

\section{RanCangan Solusi}

Data yang tersedia belum memliki label, namun pengelompokan data yang belum memiliki label dapat dilakukan berdasarkan karakteristik kemiripan data yang dimiliki. Teknik pengelompokan dengan clustering melakukan eksplorasi data untuk mendapatkan insight terhadap data yang anomali [8][9]. Salah satu metode clustering yang populer adalah $K$-Means.Pengelompokkan (clustering) item data ke dalam sekelompok data kecil berdasarkan kesamaan sifat data dilakukan dengan tujuan untuk meminimalkan jarak di dalam cluster dan memaksimalkan jarak antar cluster [3]. Dari hasil analisis akan dihasilkan 5 cluster dari data yang tersedia.

\section{A. Teknik Klustering}

Teknik clustering yang digunakan merupakan unsupervised learning yang merupakan teknik pengelompokkan machine learning yang menyimpulkan pola dari dataset tanpa mengacu pada hasil yang telah diketahui maupun yang telah diberi label [9].

K-Means Clustering merupakan salah satu metode yang termasuk ke dalam golongan algoritma Partitioning Clustering [8]. Dengan langkah-langkah sebagai berikut [10]:

1. Tentukan nilai $\mathrm{k}$ sebagai jumlah cluster yang ingin dibentuk

2. Bangkitkan $\mathrm{k}$ centroid (titik pusat cluster) awal secara acak

3. Hitung jarak setiap data ke masing-masing centroid menggunakan rumus korelasi antar dua objek (Euclidea Distance)

4. Kelompokkan setiap data berdasarkan jarak terdekat antara data dengan centroidnya

5. Tentukan posisi centroid baru ( $\mathrm{k} \mathrm{C}$ ) dengan cara menghitung nilai rata-rata dari data yang ada pada centroid yang sama.

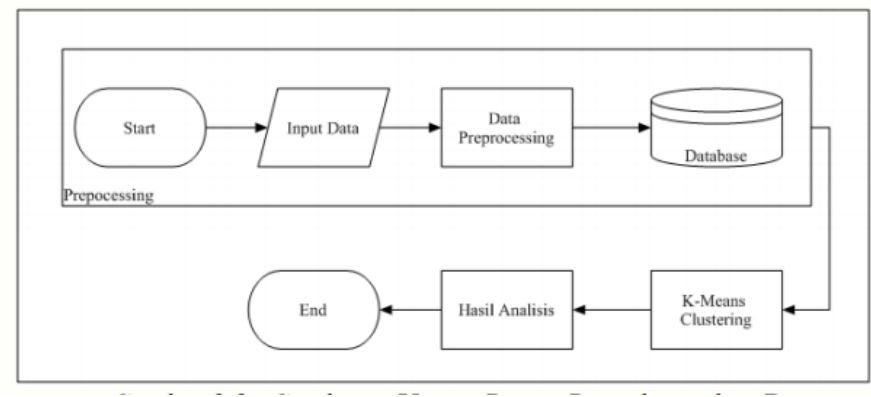

Gambar 3. Clustering data

\section{B. Evaluasi Rancangan Solusi}

Evaluasi model menggunakan silhouette coefficient untuk melihat kualitas dan kekuatan cluster, seberapa baik suatu objek ditempatkan dalam suatu cluster. Metode ini merupakan gabungan dari metode cohesion dan separation. Nilai hasil silhouette coefficient terletak pada kisaran nilai -1 hingga 1 . Jika nilai silhouette coefficient mendekati nilai 1, maka semakin baik pengelompokan data dalam satu cluster. Sebaliknya jika silhouette coefficient mendekati nilai -1 , maka semakin buruk pengelompokan data didalam satu cluster [8]. 


\section{Pengumpulan Data}

Data didapatkan dari Unit Pelayanan Teknis Angkutan Umum yang berada dibawah Dinas Perhubungan Kota Tangerang dan survei - survei yang telah dilakukan sebelumnya oleh pihak Dinas Perhubungan Kota Tangerang sejak Desember Tahun 2016 sampai dengan Maret 2019 [5][6].

\section{A. Deskripsi Data}

Data yang digunakan berupa data penumpang kendaraan BRT Trans Tangerang sejak Desember 2017 sampai dengan November 2018 yang melayani perjalanan pada Koridor 1 dari koridor Terminal Poris Plawad-Jatake yang ada dengan rincian atributatributnya sebagai berikut.

Tabel 1. Data penumpang kendaraan BRT Trans Tangerang

\begin{tabular}{|l|l|}
\hline \multicolumn{1}{|c|}{ Nama_field } & \multicolumn{1}{c|}{ Keterangan } \\
\hline Tanggal & datetime \\
\hline Hari & string \\
\hline Halte & string \\
\hline Jumlah_penumpang & integer \\
\hline
\end{tabular}

Data penumpang kendaraan BRT Trans Tangerang terdiri dari field Tanggal, Hari, Halte, dan Jumlah_penumpang sesuai Tabel 1. Data tersebut terdiri dari 365 records data berupa jumlah penumpang yang menggunakan kendaraan tersebut pada Koridor 1 untuk satu kali perjalanan yang melalui 10 (sepuluh) halte. Gambar 4 menunjuk kan contoh data penumpang kendaraan BRT Trans Tangerang pada bulan November 2018.

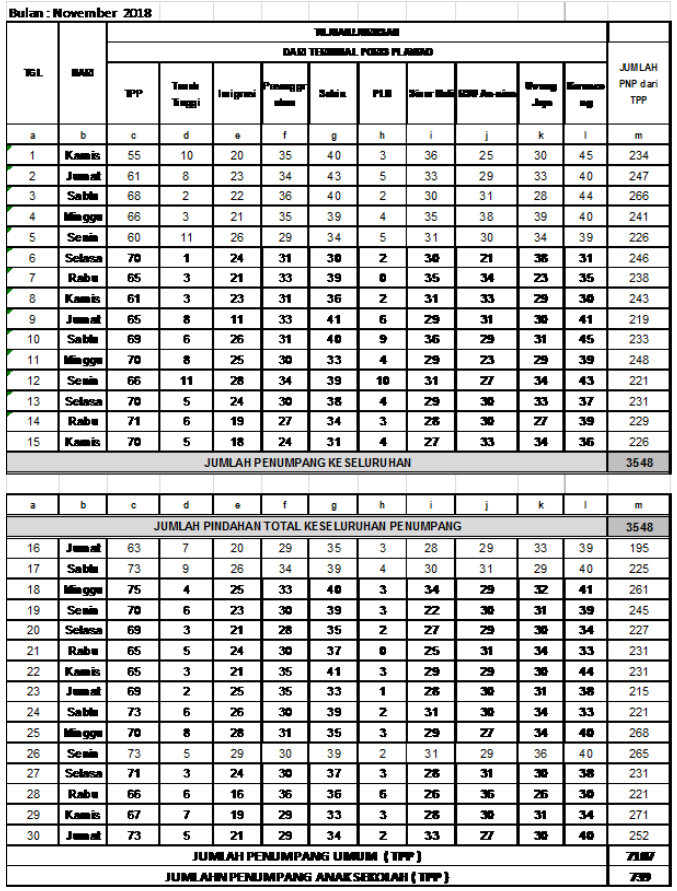

Gambar 4. Contoh data penumpang BRT Trans Tangerang 


\section{B. Proses Data}

Tahap pertama yang dilakukan adalah dengan menyeleksi seluruh data atribut pada dataset untuk mendapatkan atribut-atribut yang bernilai relevan, tidak missing value, dan tidak redundance [7]. Atribut pengujian pertama ditentukan sebanyak 3 atribut, yaitu: tanggal, hari dan jumlah penumpang, sehingga akan didapatkan sample data sebagai berikut.

\begin{tabular}{|c|c|c|c|}
\hline & Tanggal & Hari & jumlah_penumpang \\
\hline 1 & 43070.0 & Friday & 238.0 \\
\hline 2 & 43071.0 & Saturday & 442.0 \\
\hline 3 & 43072.0 & Sunday & 535.0 \\
\hline 4 & 43073.0 & Monday & 552.0 \\
\hline 5 & 43074.0 & Tuesday & 433.0 \\
\hline 6 & 43075.0 & Wednesday & 540.0 \\
\hline 7 & 43076.0 & Thursday & 572.0 \\
\hline 8 & 43077.0 & Friday & 529.0 \\
\hline 9 & 43078.0 & Saturday & 455.0 \\
\hline 10 & 43079.0 & Sunday & 681.0 \\
\hline 11 & 43080.0 & Monday & 539.0 \\
\hline 12 & 43081.0 & Tuesday & 691.0 \\
\hline 13 & 43082.0 & Wednesday & 401.0 \\
\hline 14 & 43083.0 & Thursday & 642.0 \\
\hline 15 & 43084.0 & Friday & 588.0 \\
\hline 16 & 43085.0 & Saturday & 568.0 \\
\hline 17 & 43086.0 & Sunday & 509.0 \\
\hline 18 & 43087.0 & Monday & 743.0 \\
\hline 19 & 43088.0 & Tuesday & 513.0 \\
\hline 20 & 43089.0 & Wednesday & 557.0 \\
\hline 21 & 43090.0 & Thursday & 612.0 \\
\hline 22 & 43091.0 & Friday & 516.0 \\
\hline 23 & 43092.0 & Saturday & 492.0 \\
\hline
\end{tabular}

Gambar 5. Sample data

\section{Analisis Deskriptif}

Data penumpang BRT Trans Tangerang berjumlah sebanyak 365 records. Data ini diambil pada bulan Desember 2017 hingga November 2018. Penumpang paling banyak pada data ini terjadi pada hari Senin tanggal 18 Desember 2017 sebanyak 743 orang dan paling sedikit pada hari Selasa tanggal 4 Januari 2018 sebanyak 35 orang. Rata-rata penumpang BRT Trans Tangerang per harinya adalah 340 orang.

Dalam kondisi ideal, jumlah rata-rata penumpang ini masih dapat dilayani oleh armada dan jadwal yang dilayani Koridor 1. Namun untuk hari-hari tertentu, terjadi peningkatan atau penurunan jumlah penumpang. Jumlah penumpang meningkat pada harihari tertentu seperti Minggu dan Senin. Selain itu, jumlah penumpang yang tinggi terjadi pada bulan Desember 2017 dengan rata-rata 525 orang dan yang terendah terjadi pada November 2018 .

\section{EKSPERIMEN DAN HASIL}

Variabel yang digunakan sebagai parameter berjumlah 3 buah, yaitu:

a. Tanggal

b. Hari

c. Jumlah penumpang

\section{A. Pembangunan model yang diusulkan}

Clustering pada data penumpang BRT Trans Tangerang dilakukan menggunakan teknik k-means clustering. Data ini dikelompokan ke dalam 5 (lima) cluster dengan visualisasi seperti yang digambarkan pada Gambar 6. 


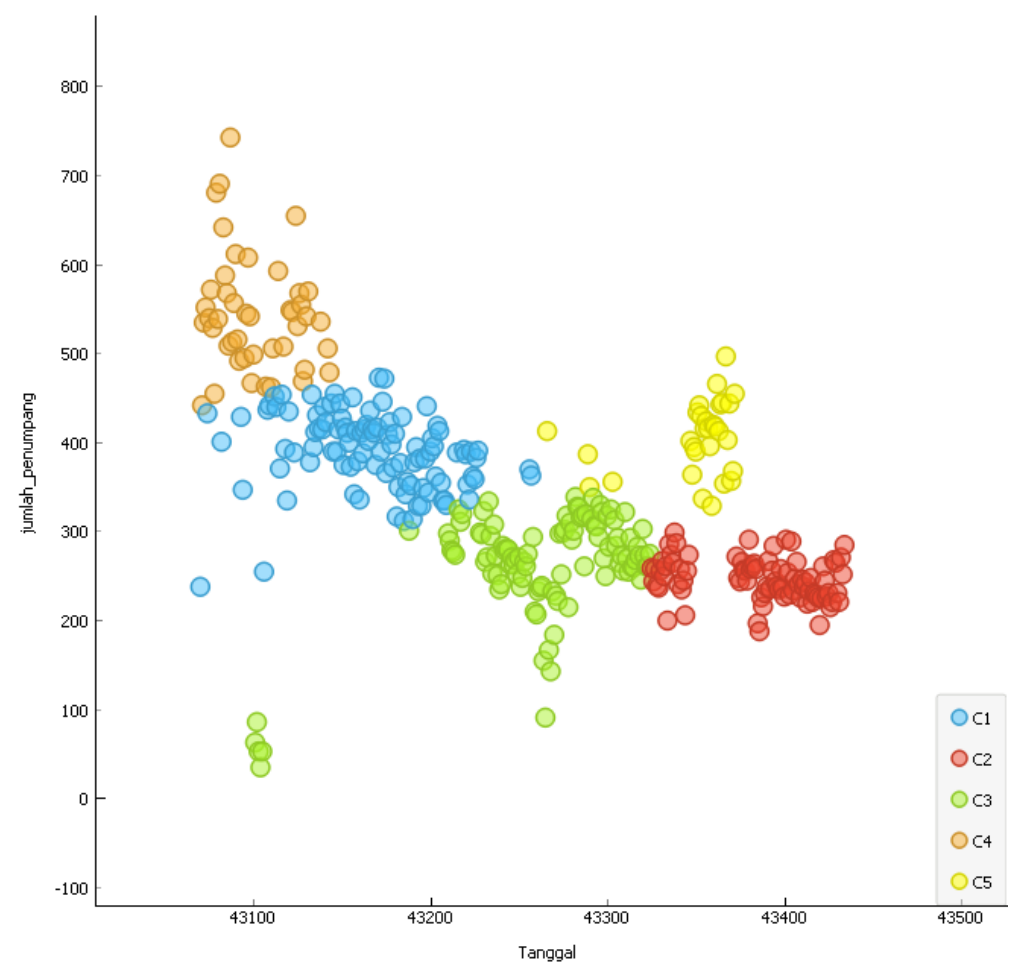

Gambar 6. Hasil clustering data penumpang BRT Trans Tangerang

Pada Gambar 6, terlihat cluster C1 dan C3 memiliki sebaran data yang lebih banyak dibandingkan cluster lainnya sedangkan cluster C5 memiliki sebaran data yang paling sedikit. Beberapa data yang merupakan pencilan tetap masuk ke dalam cluster yang paling dekat centroidnya.

Cluster C1 (berwarna biru) berisi 102 data. Cluster C2 (berwarna merah) berisi 84 data. Cluster C3 (berwarna hijau) berisi 105 data. Cluster C4 (berwarna oranye) berisi 44 data. Cluster C5(berwarna kuning) berisi 30 data. Distribusi clustering tersebut digambarkan pada Gambar 7.

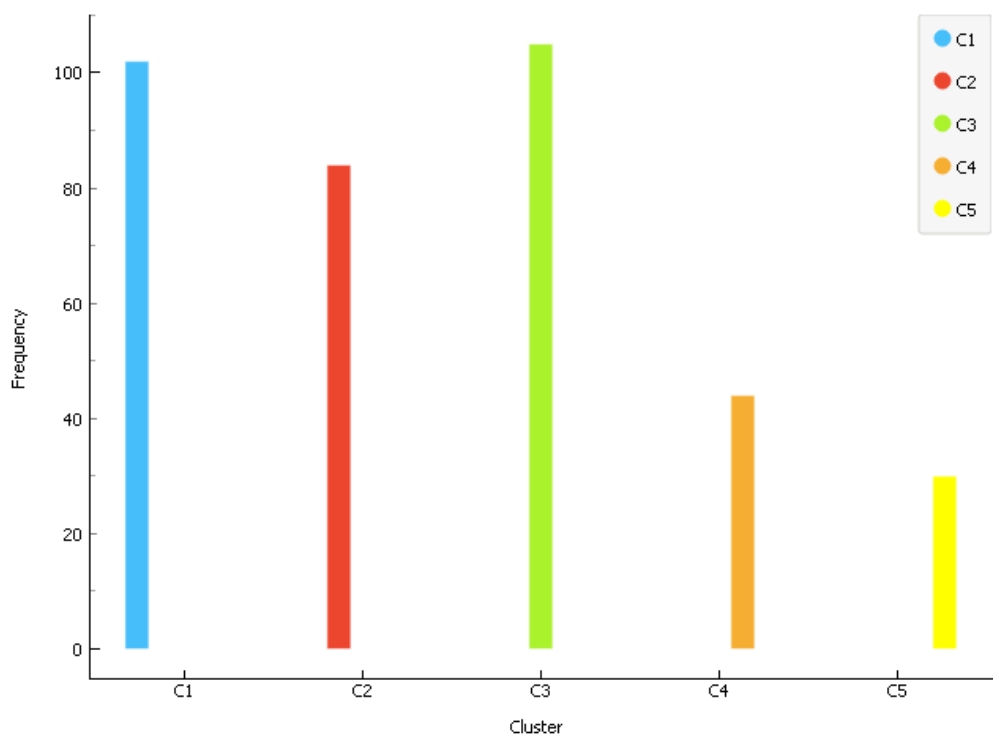

Gambar 7. Distribusi hasil clustering data penumpang BRT Trans Tangerang 
Distribusi data berdasarkan hari untuk setiap cluster ditunjukkan pada Tabel 2. Data penumpang pada hari Senin paling banyak dikelompokan ke dalam cluster C1 dan paling sedikit pada cluster C5. Data pada hari Selasa paling banyak dikelompokan ke dalam cluster $\mathrm{C} 1$ dan paling sedikit dikelompokan ke dalam cluster $\mathrm{C} 4$ dan $\mathrm{C} 5$. Data pada hari Rabu paling banyak dikelompokan ke dalam cluster $\mathrm{C} 1$ dan $\mathrm{C} 3$, sedangkan paling sedikit dikelompokan ke dalam cluster C5. Data pada hari Kamis paling banyak dikelompokan ke dalam cluster C3 dan paling sedikit dikelompokan ke dalam cluster C5. Data pada hari Jumat paling banyak dikelompokan ke dalam cluster $\mathrm{C} 3$ dan paling sedikit dikelompokkan ke dalam cluster C4 dan C5. Data pada hari Sabtu paling banyak dikelompokan ke dalam cluster C3 dan paling sedikit dikelompokkan ke dalam cluster C5. Data pada hari Minggu paling banyak dikelompokkan ke dalam cluster $\mathrm{C} 1$ dan $\mathrm{C} 3$, sedangkan paling sedikit dikelompokan ke dalam cluster C5. Visualisasi dari distribusi tersebut digambarkan pada Gambar 8 .

Tabel 2. Distribusi data berdasarkan hari

\begin{tabular}{|c|c|c|c|c|c|c|c|c|}
\hline \multicolumn{2}{|c|}{ Cluster } & Senin & Selasa & \multicolumn{2}{|c|}{ Rabu } & Kamis & Jumat & \multicolumn{2}{c|}{ Sabtu ingu } \\
\hline C 1 & 15 & 17 & 14 & 13 & 15 & 15 & 13 \\
\hline C2 & 13 & 12 & 12 & 12 & 12 & 11 & 13 \\
\hline C3 & 14 & 15 & 14 & 17 & 16 & 16 & 9 \\
\hline C4 & 6 & 4 & 8 & 6 & 5 & 6 & 5 \\
\hline C5 & 4 & 4 & 4 & 4 & 5 & 4 & 5 \\
\hline
\end{tabular}

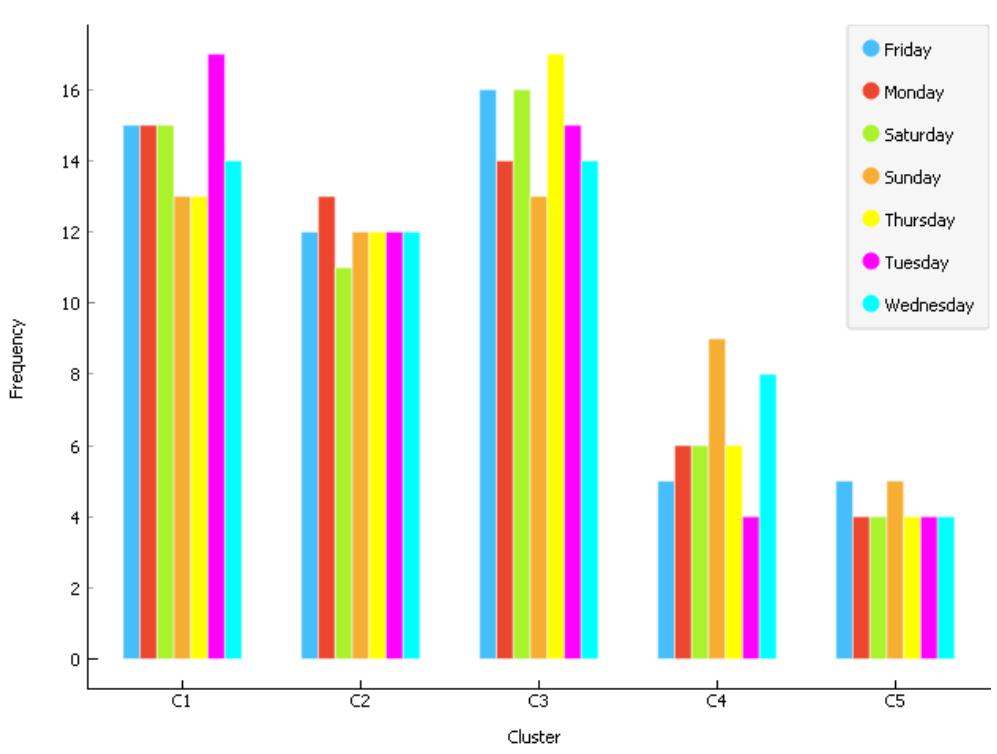

Gambar 8. Visualisasi distribusi hasil clustering data penumpang BRT Trans Tangerang berdasarkan hari

Rata-rata data penumpang BRT Trans Tangerang diperoleh sebesar 390,38 pada cluster C1;246,67 pada cluster C2; 263,74 pada cluster C3; 544,39 pada cluster C4; dan 405,47 pada cluster C5. Rata-rata tertinggi terdapat pada cluster C4 dan rata-rata terendah terdapat pada cluster C2. Cluster C4 sebagian besar diisi oleh data pada bulan Desember 2017. 


\begin{tabular}{|c|c|c|c|c|c|}
\hline & Cluster & Silhouette & Tanggal & Hari & jumlah_penumpang \\
\hline 1 & C1 & 0.528 & 43070.0 & Friday & 238.0 \\
\hline 2 & C4 & 0.506 & 43071.0 & Saturday & 442.0 \\
\hline 3 & C4 & 0.680 & 43072.0 & Sunday & 535.0 \\
\hline 4 & C4 & 0.685 & 43073.0 & Monday & 552.0 \\
\hline 5 & $\mathrm{C} 1$ & 0.519 & 43074.0 & Tuesday & 433.0 \\
\hline 6 & C4 & 0.684 & 43075.0 & Wednesday & 540.0 \\
\hline 7 & C4 & 0.686 & 43076.0 & Thursday & 572.0 \\
\hline 8 & C4 & 0.679 & 43077.0 & Friday & 529.0 \\
\hline 9 & $\mathrm{C} 4$ & 0.543 & 43078.0 & Saturday & 455.0 \\
\hline 10 & C4 & 0.653 & 43079.0 & Sunday & 681.0 \\
\hline 11 & $\mathrm{C} 4$ & 0.685 & 43080.0 & Monday & 539.0 \\
\hline 12 & C4 & 0.649 & 43081.0 & Tuesday & 691.0 \\
\hline 13 & $\mathrm{C} 1$ & 0.602 & 43082.0 & Wednesday & 401.0 \\
\hline 14 & C4 & 0.666 & 43083.0 & Thursday & 642.0 \\
\hline 15 & C4 & 0.684 & 43084.0 & Friday & 588.0 \\
\hline 16 & C4 & 0.688 & 43085.0 & Saturday & 568.0 \\
\hline 17 & C4 & 0.665 & 43086.0 & Sunday & 509.0 \\
\hline 18 & C4 & 0.631 & 43087.0 & Monday & 743.0 \\
\hline 19 & C4 & 0.669 & 43088.0 & Tuesday & 513.0 \\
\hline 20 & C4 & 0.689 & 43089.0 & Wednesday & 557.0 \\
\hline 21 & C4 & 0.677 & 43090.0 & Thursday & 612.0 \\
\hline 22 & C4 & 0.672 & 43091.0 & Friday & 516.0 \\
\hline 23 & C4 & 0.638 & 43092.0 & Saturday & 492.0 \\
\hline 24 & $\mathrm{C} 1$ & 0.565 & 43093.0 & Sunday & 429.0 \\
\hline 25 & $\mathrm{C} 1$ & 0.646 & 43094.0 & Monday & 347.0 \\
\hline 26 & C4 & 0.644 & 43095.0 & Tuesday & 495.0 \\
\hline 27 & C4 & 0.688 & 43096.0 & Wednesday & 545.0 \\
\hline 28 & C4 & 0.678 & 43097.0 & Thursday & 608.0 \\
\hline 29 & C4 & 0.687 & 43098.0 & Friday & 542.0 \\
\hline 30 & C4 & 0.564 & 43099.0 & Saturday & 467.0 \\
\hline 31 & $\mathrm{C} 4$ & 0.649 & 43100.0 & Sunday & 499.0 \\
\hline 32 & $\mathrm{C} 3$ & 0.568 & 43101.0 & Monday & 63.0 \\
\hline 33 & $\mathrm{C} 3$ & 0.567 & 43102.0 & Tuesday & 86.0 \\
\hline 34 & $r_{3}$ & 0568 & $\triangle 31030$ & Wednesdav & 530 \\
\hline
\end{tabular}

Gambar 9. Contoh data hasil clustering

\section{B. Evaluasi model}

Nilai silhouette coefficient yang didapat dari penelitian ini dihasilkan nilai antara 0,456 sampai dengan 0,708 , hal ini menunjukkan jika model yang didapat sudah cukup baik.

\section{KESIMPULAN dAN SARAN}

\section{A. Kesimpulan}

Hasil clustering memiliki sifat yang hampir sama antara data-data yang berada dalam satu cluster, yaitu jumlah penumpang secara total perbulannya, sehingga dengan melakukan karakteristik clustering, pengetahuan mengenai jadwal padatnya penumpang dalam satu hari dapat membantu pihak terkait untuk mengantisipasi padatnya penumpang pada hari tertentu.

\section{B. Saran}

Berdasarkan hasil penelitian diatas dapat disimpulkan bahwa hasil klustering dapat lebih bermanfaat jika dataset yang digunakan lebih terperinci, seperti tipe penumpang, jumlah penumpang naik dan turun di setiap halte, jam kedatangan dan jam keberangkatan BRT, dan lain-lain. 


\section{Daftar Pustaka}

[1] Adeliani, A (2018): Efektivitas Pengelolaan Bus Rapid Transit Trans Tangerang, Skripsi, Universitas Sultan Ageng Tirtayasa.

[2] Data Halte Kota Tangerang. Dinas Perhubungan Kota Tangerang. 2017.

[3] Handoko, K., and Lesmana, L. S. (2018): Data Mining Pada Jumlah Penumpang Menggunakan Metode Clustering, (1), 97-102.

[4] Identifikasi Titik Kemacetan dan Permasalahannya di Kota Tangerang Tahun 2013 Sekarang. Dinas Perhubungan Kota Tangerang. 2017.

[5] Laporan UPTD Angkutan Umum Massal Dinas Perhubungan Kota Tangerang Tahun Anggaran 2017.

[6] Laporan UPTD Angkutan Umum Massal Dinas Perhubungan Kota Tangerang Tahun Anggaran 2018.

[7] Praja, B. S., Purba D.K, dan Setianingsih C, (2018): Penerapan Metode K-Means Clustering Dalam Pengelompokan Data Penumpang Dan Kapal Angkutan Laut Di Indonesia Aplication Of K-Means Clustering Method In Passenger And Ship Transport Data Grouping In Indonesia.

[8] Tilley, S., dan Rosenblatt, H. (2017): Systems Analysis and Design, eleventh, Boston: Cengage Learning.

[9] Rahmat, Arif. "Survei Penerapan Model Machine Learning dalam Bidang Keamanan Informasi". Jurnal Sistem Cerdas 2019 vol 02 pp. 47-60

[10] Zakiul Fahmi Jailani (2015) : Pola Persebaran Penumpang Pada Shuttle Bus Trans Jogja Menggunakan Algoritma Simple K-Means, Makalah, STIMIK AMIKOM Yogyakarta. 